\title{
A TRAJETÓRIA DE ODILON LOPEZ - UM PIONEIRO DO CINEMA NEGRO BRASILEIRO
}

\author{
The trajectory of Odilon Lopes - a pioneer \\ of Brazilian black cinema
}

Noel dos Santos Carvalho*

\begin{abstract}
RESUMO
Este artigo investiga a trajetória do cineasta Odilon Lopez. Inicialmente faz uma breve contextualização sobre a centralidade do afro-brasileiro no cinema brasileiro com a eclosão do Cinema Novo e o despontar dos primeiros realizadores negros. Em seguida descreve o percurso cinematográfico de Odilon Lopez desde os primeiros anos de atividade na televisão até a realização do seu filme Um é pouco, dois é bom em 1970.
\end{abstract}

Palavras-chave: negro; cinema; política.

\begin{abstract}
This article investigates the trajectory of the filmmaker Odilon Lopez. Initially, it presents a brief background on the centrality of the African-Brazilian in Brazilian cinema with the rising of the Cinema Novo and the emergence of the first black performers. Then it describes the cinematic journey of Odilon Lopez from his first years of activity on television until the completion of his film a Um é pouco, dois é bom in 1970.
\end{abstract}

Keywords: Black; Cinema; policy.

* Noel dos Santos Carvalho é doutor em Sociologia (USP), documentarista e professor de cinema no Instituto de Artes da Universidade Estadual de Campinas, UNICAMP. 


\section{Cinema Novo e Cinema Negro}

Na década de 1950 o sociólogo Guerreiro Ramos escreveu: “O negro é povo no Brasil" (RAMOS, 1995, p. 200). Nos anos 1960 a geração de jovens cineastas que criou o Cinema Novo traduziu em imagens e sons estas palavras. Todas as vezes que os filmes trataram do pobre, do sambista, do proletariado, do malandro, do morador do morro - tropos do povo - recorreram aos atores negros e mulatos. ${ }^{1}$

As representações criadas pelos cinemanovistas não ficaram restritas aos tipos sociais. A cultura, a história e os problemas cotidianos da população negra foram dramatizados nas obras da primeira fase do movimento. ${ }^{2}$

Em 1965, durante a V Resenha do Cinema Latino-Americano realizado em Genova o cineasta David Neves apresentou a comunicação, O Cinema de Assunto e Autor Negros no Brasil, ${ }^{3}$ na qual escreveu: “(...) no panorama cinematográfico brasileiro, emergiram cinco filmes que serão, no método indutivo que proponho adotar aqui, as bases de uma modesta fenomenologia do cinema negro no Brasil." (NEVES, 1968, p. 75). Ou seja, nos termos de Neves, o Cinema Novo colocou as bases de um cinema negro brasileiro.

1 Em outro artigo discuto o que os intelectuais identificados com a ideologia nacionalista entendiam por povo. Ver: CARVALHO, N. S. Produção, Mercado Cinematográfico e Ideologia Nacionalista - O Cinema Brasileiro Sob a Égide do Nacional - Popular nos Anos 50. Ponta de Lança, (UFS), Sergipe, V. 6, n 12, 2012. Disponível em: <http://seer.ufs.br/index.php/pontadelanca/article/view/3326>. Acesso em: 05 abr. 2015

2 Para efeito didático, os estudiosos dividem o Cinema Novo em três períodos. $\mathrm{O}$ primeiro corresponde ao surgimento dos primeiros filmes até o golpe militar em 1964. O segundo compreende os filmes realizados após o golpe até aproximadamente 1968. A terceira fase perdura até os anos 70, momento de acirramento da censura e da repressão, quando os filmes passam a assumir fortes tons alegóricos. Ver: RAMOS, F. (Org.). História do cinema brasileiro. São Paulo, Art. Editora, 1990; XAVIER, I. Do golpe militar à abertura: a resposta do cinema de autor. In: XAVIER, I.; BERNARDET, J-C.; PEREIRA, M. O desafio do cinema. Rio de Janeiro, Jorge Zahar, 1985.

3 Este texto foi analisado detalhadamente em dois trabalhos meus. Ver: CARVALHO, N. S. Cinema e representação racial - o cinema negro de Zózimo Bulbul. 2006. 302 p. (Tese de Doutorado em Sociologia) - Universidade de São Paulo, São Paulo, 2006; CARVALHO, N. S. Racismo e anti-racismo no Cinema Novo. In: Esther Hamburguer, Gustavo Souza, Leandro Mendonça, Túnico Amancio. (Org.). Estudos de Cinema SOCINE. São Paulo: Annablume, 2008, v. , p. 53-60. Sobre a V Resenha do Cinema Latino-Americano ver: PEREIRA, M. "O Columbianum e o cinema brasileiro". Alceu, Rio de Janeiro, v. 8, n. 15, p. 127-142, jul./dez. 2007. 
No mesmo ano a Revista Civilização Brasileira publicou um debate com os diretores Gustavo Dahl, Carlos Diegues, David Neves, Paulo César Saraceni e Alex Viany para avaliar a participação do Brasil no encontro. Segundo Dahl a possibilidade de um cinema negro esteve alinhada ao cinema africano, mas protagonizada no Brasil pelos realizadores do Cinema Novo:

Em verdade, em matéria de cinema negro, o que se pode discutir foi o cinema brasileiro. E isso de tal modo que os africanos, quando queriam discutir seus problemas, se referiam freqüentemente aos filmes brasileiros e mais especialmente a Ganga Zumba, que estava muito perto das coisas que eles queriam fazer. (...) Portanto as coisas que mais me impressionaram em Gênova foram, de um lado, a imensa capacidade de diálogo com os africanos (...). (VIANY, 1965, p. 231)

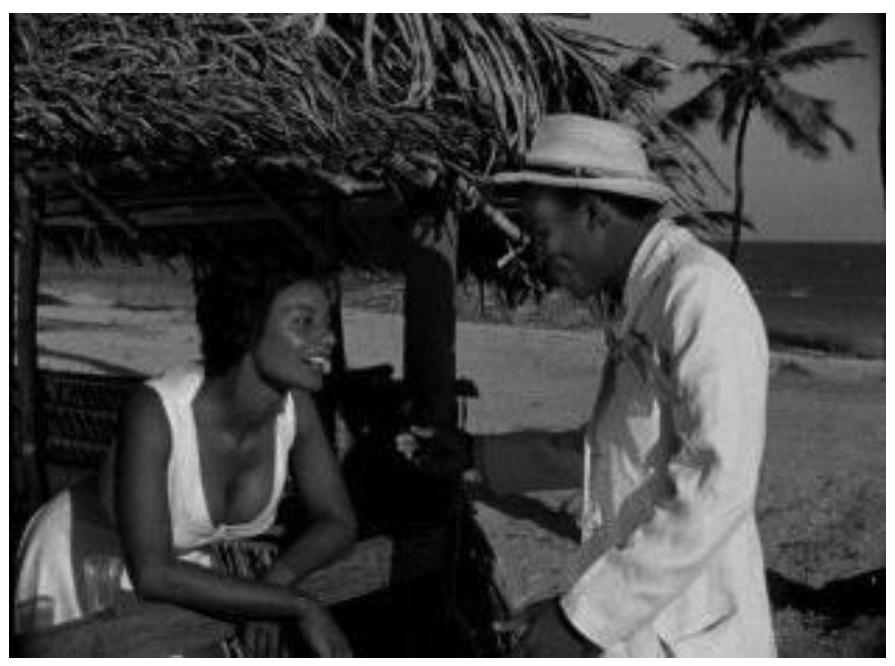

Imagem 1 No Cinema Novo o negro ocupou o centro da cena. Acima Luiza Maranhão e Antonio Pitanga no filme Barravento (Glauber Rocha, 1962) 
Nos quadros do Cinema Novo gestou-se a primeira geração de cineastas negros cujos principais são Zózimo Bulbul, Valdir Onofre e Antonio Pitanga. Os três começaram como atores e (ou) assistentes e anos depois incursionaram na produção e direção dos seus filmes. A relação com o movimento foi visceral: Nelson Pereira dos Santos produziu o filme de Valdir Onofre, As aventuras amorosas de um padeiro, em 1976; Carlos Diegues produziu e, junto com Leopoldo Serran, escreveu o argumento do filme dirigido por Antonio Pitanga, Na boca do mundo, de 1979. Com exceção de Zózimo Bulbul, nem todos produziram continuamente, mas foram o marco inicial de um cinema voltado para a temática negra realizado por cineastas negros.

No final dos anos 1970 outro diretor da mesma geração, Orlando Senna, publicou o texto Preto-e-branco ou colorido: o negro e o cinema brasileiro, no qual faz uma revisão da trajetória do negro no cinema brasileiro desde o período silencioso até os anos 1970. Constata os limites ideológicos dos cinemanovistas para tratar do negro e destaca o aparecimento de diretores oriundos do meio negro como Zózimo Bulbul, Valdir Onofre, Antonio Pitanga, Quim Negro entre outros. ${ }^{4}$

A aposta de Senna é a de que o cinema dos realizadores negros seria uma nova fase do cinema brasileiro, produzido pelo mais autêntico representante do povo. Retoma assim, trinta anos depois, um tema caro ao pensamento nacionalista negro com o qual abrimos o artigo: a sinonímia entre negro e povo.

\section{"Minha câmera são os seus olhos e meus ouvidos os seus"}

A frase do subtítulo acima expressa a postura demiúrgica recorrente entre os jovens intelectuais e artistas nos anos 1960 que se

$4 \mathrm{O}$ texto de Senna avança em relação ao de David Neves na explícita adesão às teses dos movimentos negros que desde os anos 1970 reivindicavam a identidade negra. Por extensão rompe com a tese negro/povo, tão cara ao Cinema Novo e ao nacional-populismo. 
colocaram como porta-vozes de pessoas e eventos. Ela foi adotada como lema por Odilon Lopez quando documentou a Campanha pela Legalidade em 1961..$^{5}$

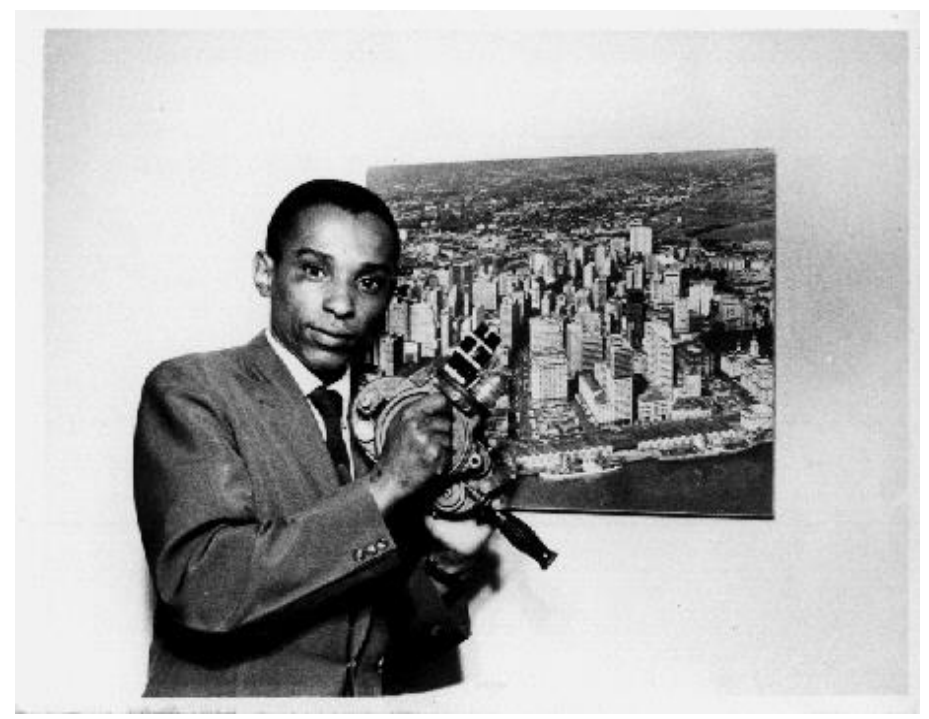

Imagem 2 A formulação cinemanovista "Uma câmera na mão e uma ideia na cabeça.", soou como toada para a geração de jovens que viu o cinema como veículo de transformação social. Acima Odilon Lopez no início da carreira.

Odilon Albertinence Lopez nasceu em 1941 no Estado de Minas Gerais, no bucólico município de Raul Soares, localizado entre os rios Matipó e Santana, Zona da Mata. A infância e a adolescência não foram fáceis. Órfão de pai e mãe, foi criado pelos avós em Belo Horizonte. Muito cedo apaixonou-se pelo cinema assistindo aos filmes de Carlitos. Com a morte do avô foi morar como interno em um abrigo para menores na cidade do Rio de Janeiro.

5 Ver: LOPEZ, O. A. "Movidos pelo carisma de um revolucionário." In: CHEUICHE, A. (Org.). Nós e a legalidade, depoimentos. Porto Alegre, Editora AGE, 1991. 
Minha paixão pelo cinema (...) começou aos sete anos de idade, quando no cinema Bagdá de Belo Horizonte, assisti "Luzes da Cidade" de Chaplin. Naquele dia, senti que um dia veria meu nome num cartaz. Mas a vida tem sido meio difícil pois logo no dia seguinte em que me deslumbrei com Carlitos, perdi meu avô e como sou órfão de pai e mãe, fui interno para o Rio de Janeiro. Aquele sonho porém persistiu (...). ${ }^{6}$

$\mathrm{Na}$ capital fluminense fez um pouco de tudo, foi engraxate, auxiliar de sapateiro e cobrador de ônibus. Começou a trabalhar no cinema em duas importantes produtoras cariocas da época: a Flama Filmes, fundada por Moacyr Fenelon e Rubens Berardo, e a Brasil Vita Filmes da atriz e produtora Carmen Santos. Nesta fase estudou atuação na escola de preparação de intérpretes fundada por Sérgio Sckera e Gilda Mattia, dois atores italianos que desembarcaram na cidade em $1956 .^{7}$

Em 1958, com apenas 17 anos, iniciou os primeiros trabalhos profissionais. Fez assistência de câmera e cinegrafia para o diretor de fotografia argentino Mário Pagés ${ }^{8}$ no filme Aguenta o rojão (Watson Macedo, 1958). Atuou e fez assistência de câmera para Juan Carlos Landini $^{9}$ no filme No mundo da lua (Roberto Farias, 1958). Em seguida trabalhou com o fotógrafo Afrodisio de Castro em $O$ batedor

6 RIBEIRO, C. Desfile. A Hora, Porto Alege, 15 fev. 1960.

7 Os dois atores abriram uma companhia de teatro e uma escola de arte e interpretação cinematográfica na Avenida Oswaldo Cruz, em Botafogo. Sckera frequentou a Academia de Belas Artes de Nápoles e o Centro Experimental de Cinematografia em Roma, escreveu e dirigiu peças para o teatro de revistas, entre elas Tem pimenta no cús - cús, Gerarda... naquela base, Tem rififi no rufufu, entre outras. Gilda trabalhou como atriz. Ver "Gilda Mattia e Sergio Sckera - dois artistas do teatro e do cinema da Itália." Correio da Manhã, sábado, 14 de dezembro de $1957,1^{\circ}$ Caderno, p.13.

8 Fotógrafo cinematográfico argentino com longa experiência no cinema do seu país, veio ao Brasil nos anos 1950 para trabalhar na Companhia Cinematográfica Maristela. Trabalhou ainda nos estúdios cariocas da Flama Filmes e da Brasil Vita Filmes. Nos anos 1960 trabalha na instalação da TV Globo e organiza o sistema de iluminação do departamento de reportagem e jornalismo. Morre no final dos anos 80 (SILVA NETO, 2010, p. 108).

9 Juan Carlos Landini, outro fotógrafo argentino veio trabalhar na Companhia Cinematográfica Maristela trazido pelo amigo Mário Pagés. Fez a fotografia de filmes como Suzana e o Presidente (1951), Simão, o Caolho (1952), Meu Destino é Pecar (1952), etc. Nas décadas de 60, 70 e 80 trabalha em publicidade e televisão. Faleceu em 18 de outubro de 1999, aos 84 anos de idade, em São Paulo. (SILVA NETO, 2010, p. 82). 
de Carteiras (Aluizio T. de Carvalho, 1958) e Traficantes do crime (Mario Latini, 1958).

Em 1959 viaja para o Rio Grande do Sul para trabalhar como cinegrafista na empresa Brás Filme. Como ele, muitos técnicos e artistas chegavam à Porto Alegre para trabalhar no então aquecido mercado de televisão gaúcho. ${ }^{10}$ Mila Cauduro, no livro Palavras do tempo, rememora esta passagem da vida do cineasta.

Com seus dezoito anos incompletos, reunindo o destemor do mitológico Ulysses, pensando repetir Marco Pólo na conquista de outros mundos, obstinado em seguir os passos de Chaplin e Fellini na arte da imagem em movimento e som, desembarcava, no aeroporto Salgado Filho, a figura esquálida de tez melânica de Odilon Lopez. Viera contratado pela empresa Brás Filme para filmar documentários e cinejornais que proliferavam na época. Mais tarde, confessou-me ele sentir-se humilhado naquele trabalho cinematográfico, sem equipe e preocupação artística, porém acreditou estar ali a oportunidade de tornar-se um grande cineasta (CAUDURO, p. 137-138).

Procurou então o diretor da rádio Farroupilha, Nelson Silva, para trabalhar como locutor. Este aconselhou o rapaz: "Aqui não é o seu lugar. Você gosta de estudar e tem cultura muito acima da média. Menino, vai para a televisão!” (CAUDURO, 2000, p. 138). Conselho que o menino, e depois o adulto, seguiram à risca.

Em 1961 ingressou como ator e Repórter Cinematográfico na TV Piratini ${ }^{11}$. Odilon foi um dos pioneiros no jornalismo televisivo, a atividade não existia até sua regulamentação pelo Decreto-Lei 972 de 1969.

10 Sobre a fundação e os primeiros anos da televisão no Rio Grande do Sul ver: REIS, L. P. S. O backstage da televisão no Rio Grande do Sul. 2012. 296 p. (Dissertação de mestrado em Comunicação Social) - Pontifícia Universidade Católica do Rio Grande do Sul, Porto Alegre, 2013.

11 Primeira emissora de TV do Rio Grande do Sul, criada por Assis Chateaubriand em 1959. 
A prática do Repórter Cinematográfico não era fácil nesses primeiros anos e exigia do jornalista talentos até então inimagináveis. Ele era um factótum da informação: selecionava e enquadrava as imagens, fazia o plano, operava a câmera, revelava e secava o negativo, pré-editava as imagens e, não raramente, redigia o texto. Algumas dessas funções eram realizadas em locação, no calor da hora, em situações tensas de comícios, entrevistas, acidentes e manifestações de rua.

Os equipamentos eram limitados se comparados aos atuais. As primeiras câmeras utilizadas eram os modelos Bell \& Howell que rodavam com filmes de $16 \mathrm{~mm}$. Embora compactas e leves para a época, tinham um tempo de apenas 2,5 minutos de filmagem.

As condições de filmagem em campo exigiam o olhar certeiro do repórter e escolha da melhor posição sem desperdício do filme. Nas tomadas internas, quase todas com pouca luminosidade, contava-se com um auxiliar, o "pau-de-luz". ${ }^{12}$ Como as câmeras não gravavam os sons, ficava a cargo do repórter tanto a redação do texto quanto a edição das imagens, ou seja, a "matéria" pronta para a transmissão. Nas palavras de Odilon:

A função do cinegrafista da época (...) nós éramos os olhos do telespectador (...), porque nós tínhamos que ir ao local coletar a notícia, filmar e trazer de volta, e contar a história que aconteceu. E com um problema, nós não tínhamos a vantagem de hoje com videoteipe. ${ }^{13}$

12 Segundo REIS (2013) "O 'pau-de-luz' tinha este nome por carregar o modesto equipamento que iluminava as cenas a serem captadas: era uma cruz de madeira, cerca de um metro de altura por $50 \mathrm{~cm}$., nos braços. Na extremidade superior e nas pontas dos braços, estavam instaladas lâmpadas de 150 watts cada." (p. 52)

13 Depoimento de Odilon Lopez. Disponível em <https://www.youtube.com/watch?v=d4781CipW8k>. Acesso em: 24 mar. 2015. 
E acrescenta: "Na época, as filmadoras não eram sonoras, isto é, não tinham som simultâneo e eram à corda, o que exigia do cinegrafista dupla atenção: filmar e ser repórter." ${ }^{14}$

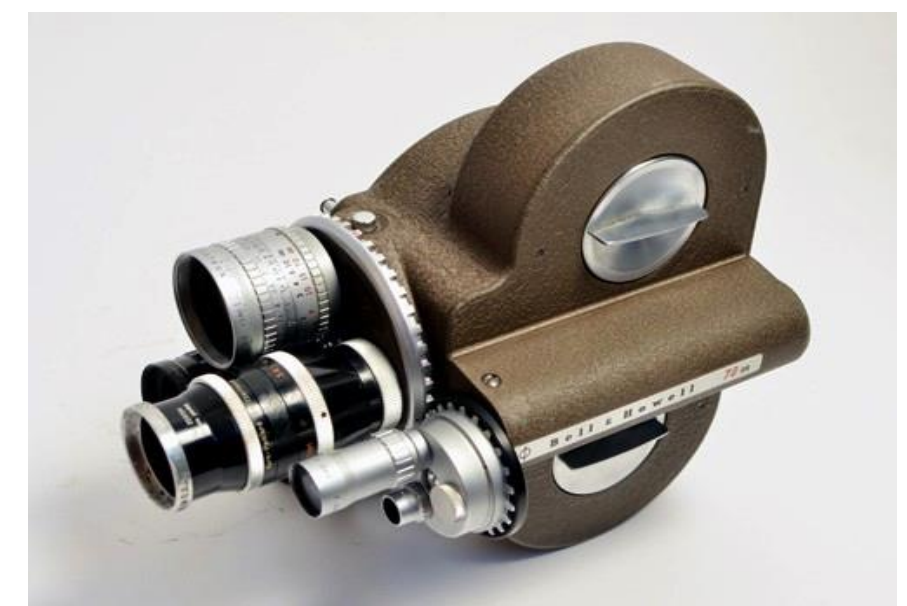

Imagem 3 Câmera Bell \& Howell 70DR "Filmo" 16mm. Modelo da câmera cinematográfica utilizada para reportagens e documentários .

Em 1961 Odilon cobriu a Campanha da Legalidade no Rio Grande do Sul quando setores militares tentaram impedir a posse de João Goulart após a renúncia de Jânio Quadros. Capitaneados pelo então governador do Estado Leonel Brizola, os legalistas montaram a Rede Nacional da Legalidade. Utilizaram a Rádio Guaíba, cujos transmissores foram transferidos para o subsolo do Palácio Piratini, sede do governo do Estado. Através dela políticos, artistas e ativistas passavam suas mensagens, o governador Brizola falava com a população e proclamava os seus inflamados discursos de resistência. ${ }^{15}$

\footnotetext{
14As informações sobre a o trabalho de Odilon como repórter cinematográfico foram obtidas do artigo de Yuri Victorino. Disponível em: <http://projetoresyuri.blogspot.com.br/2011/09/tv-piratini-esta-no-ar.html>. Acesso em: 20 mar. 2015. Ver também: LOPEZ, O. A. "Movidos pelo carisma de um revolucionário.” In: CHEUICHE, A. (Org.). Nós e a legalidade, depoimentos. Porto Alegre, Editora AGE, 1991.

15 Sobre o movimento pela legalidade e o papel que os meios de comunicação ver: MARKUN, P.; HAMILTON, D. 1961: Que as armas não falem. São Paulo, SENAC, 2001.
} 
Além de documentar os eventos principais, Lopez atuou politicamente na organização da resistência à tentativa de golpe. Participou da criação do Comitê de Artistas e Intelectuais pela Legalidade. Na rádio lia telegramas em inglês, francês, espanhol e italiano, difundindo o movimento para o mundo. Durante o dia fazia plantão no aeroporto Salgado Filho para registrar entradas e saídas de políticos e lideranças. Registrou em filme a chegada dos soldados da brigada militar, a montagem das metralhadoras na torre da igreja da matriz e a movimentação da multidão na Praça Marechal Deodoro (Praça da Matriz). A descrição abaixo é ilustrativa desses agitados dias.

O Palácio Piratini foi transformado na cidade de defesa aos preceitos constitucionais, e em seus porões os jornalistas produziam noticiários que mantinham o povo brasileiro - e do exterior — informado sobre a Legalidade e a disposição para a luta armada. Naquele tempo, as comunicações não eram tão fáceis e instantâneas como em nossos dias. Se davam por rádio, telégrafo, radio-amador, teletipos com recepção truncada e telefone com ligações demoradas e por vezes inaudíveis. Tais desconfortos alimentavam a boataria cuja central, até por ser domingo, era o Largo dos Medeiros e cercanias. [...] A manhã fora tensa e de muitos boatos que, de repente, à tarde, cessaram. Nem sempre vale a máxima inglesa: No news, good news. Ao anoitecer recrudesceram os boatos: o Exército recebeu ordens de prender o Governador Brizola. Ou: os tanques de guerra da Serraria têm ordens para atacar o Palácio Piratini, depor e prender o Governador dos gaúchos. O Largo dos Medeiros e a Praça da Alfândega iam se enchendo de gente, entre eles muitos jornalistas, que traziam novos boatos ou analisavam os já existentes.

[...] O clima era de guerra e nervosismo geral. Horas mais tarde era chegada a vez dos civis serem armados, e o jornalista Neri Nascentes Garcia distribuía armas de fogo para aqueles que iriam resistir junto com o Governador Brizola. Eram revólveres novos, fuzis e metralhadoras. Por ser jornalista, talvez, e ali estar desde a primeira hora, apesar do meu verdadeiro pavor a armas 
de fogo, ganhei uma metralhadora portátil. Era mais um peso a carregar a tiracolo: sacola com latas de filme negativo - usávamos filmes $16 \mathrm{~mm}$, preto e branco, negativo, em latas de 100 pés cada (cerca de 2 minutos e meio de projeção cada rolo) — papéis para anotações, a filmadora, lentes sobressalentes e filtros, e ... a metralhadora. Aumentava o nervosismo e suspense na proporção direta em que iam chegando as informações. ${ }^{16}$

Lamentavelmente a maior parte do material filmado foi "perdido". Anos depois, visando uma bolsa de estudos de cinema e televisão nos Estados Unidos, Lopez apresentou para a embaixada estadunidense um currículo com parte dos seus trabalhos. Diante da demora na devolução dos filmes, o então adido cultural da embaixada, Mr. Barret, informou que o material havia extraviado, o que não convenceu. Cinicamente a embaixada "presenteou" o cineasta com o dobro de filme virgem. Segundo Odilon: "Os pesquisadores, porém, certamente encontrarão farto material na CIA norte-americana ou Biblioteca do Congresso." 17

Odilon trabalhou também como ator fazendo pontas, primeiro na TV Piratini, depois na TV Gaúcha. Ainda em 1961 integrou ao lado de Ítala Nandi, Paulo José, Paulo Cesar Pereio, Fernando Peixoto, Ivete Brandalise e Milton Mattos a peça $O$ despacho. ${ }^{18} \mathrm{O}$ texto, escrito por Mário de Almeida, entrou em cartaz em julho de 1961 e era uma sátira musical sobre a situação política do Brasil no período. Curiosamente, foi escrita antes da renuncia do presidente Jânio Quadros e tematizava um golpe de Estado. Criticava os pendores golpistas de Carlos Lacerda e da União Democrática Nacional (UDN). Seu teor político chamou a atenção da população e

16 Disponível em: <http://projetores-yuri.blogspot.com.br/2011/09/tv-piratini-esta-noar.html >. Acesso em 20 mar. 2015.

17 Disponível em: <http://www.sul21.com.br/jornal/movidos-pelo-carisma-de-umrevolucionario/>. Acesso em 20 mar. 2015.

18 Os atores faziam parte do grupo Teatro de Equipe que tinha uma postura política influenciada pelo trabalho do Teatro de Arena e do CPC da UNE. A peça estreou em 18 de julho de1961, à poucos dias da renúncia do presidente Janio Quadros. Ver: BALBI, M. Fernando Peixoto: em cena aberta. São Paulo, Imprensa Oficial do Estado de São Paulo, 2009. p. $42-51$. 
do então governador Leonel Brizola, que financiou a apresentação do espetáculo em São Paulo, Brasília e Rio de Janeiro.

Em 1962 Odilon se transfere para a recém fundada TV Gaúcha, atual RBS. Na nova emissora filmou os eventos finais do Golpe Militar de 1964 em Porto Alegre. Em meio à crise política, no dia 2 de abril, Jango voou de Brasília para a capital gaúcha para se reunir com os seus aliados políticos. Ao chegar ao aeroporto Salgado Filho, de madrugada, foi escoltado até a residência do general do III Exército, Ladário Telles, onde se reuniu com Brizola. Poucas horas depois deixou a capital e partiu para o exílio. Repórter experiente, Odilon fincou o pé e fez campana na saída da residência do general. O esforço valeu-lhe o único e último registro de João Goulart partindo do Brasil. O presidente que se exilou no Uruguai e morreria tempos depois. Segundo CASTRO (2011, p. 257):

As cenas filmadas por Lopez em Porto Alegre são rápidas. Mostram o largo da prefeitura, onde se concentraram os populares conclamados por Brizola para resistência; a polícia militar chegando em caminhões, e muita correria. Havia sido montado um dispositivo para cobertura pela televisão de todo evento. Jango foi buscado no aeroporto com tanques transitando pela Avenida Farrapos, cenas que ficaram inéditas na televisão até 1988. (...)

Pela manhã, por volta das $09 \mathrm{~h} 30 \mathrm{~min}$, os assessores de João Goulart despistaram a imprensa dizendo que o presidente ia fazer uma visita às instalações de uma obra do governo federal, ainda não concluída. Quase toda a imprensa saiu para a localidade anunciada. Entretanto, Odilon López ficou e filmou a saída de Jango de carro para o Aeroporto São João (futuro Salgado Filho).

Nos anos 1960 Odilon especializou-se em reportagens e documentários para a televisão, alguns deles premiados pela Associação Riograndense de Imprensa (ARI). Fez cursos na Europa, primeiramente em Glasgow e depois na Alemanha. Em 1967 viajou para a Bolívia, acompanhado do também jornalista Carlos Alberto 
Kolecza, para uma série de reportagens sobre a guerrilha no país. A dupla fez a cobertura do julgamento do guerrilheiro Regis Debray que havia lutado ao lado de Che Guevara.

Paralelamente à carreira de jornalista trabalhou como ator em peças e filmes. Atuou no filme Coração de Luto (Eduardo Llorente, 1967), A palavra cão não morde (Sergio Amon e Roberto Henkin, 1982) e $O$ velho do saco (Milton do Prado e Amabile Rocha, 1999). Nos anos 1960 dirigiu seu primeiro filme, o curta-metragem Um dia de chuva. Em 1982 realizou Jamboree, apresentado no Festival de Gramado do mesmo ano (MERTEN, 2002, p. 58; BECKER, 1986, p. 34).

\section{Um é pouco, dois é bom}

Em 1970 Odilon Lopez fundou a produtora Super Filmes e iniciou os preparos para a produção do seu único filme ficcional de longa-metragem, Um é pouco, dois é bom. Escreveu o argumento e convidou o escritor Luiz Fernando Veríssimo para fazer os diálogos.

O título do filme é uma referência aos dois episódios que formam o longa-metragem intitulados Com um pouquinho de sorte e Vida nova por acaso. Cada um tem duração de pouco mais de 48 minutos e juntos totalizam projeção de 97 minutos. ${ }^{19}$ A divisão em episódios não agradou ao diretor que pretendia desenvolver cada história separadamente. Anos mais tarde declarou: "Confesso que, hoje em dia, não manteria as duas histórias num mesmo filme. Daria um tratamento separado e mais profundo, mas não me envergonho da obra" (LOPEZ, 1982, p. 18).

O primeiro episódio, Com um pouquinho de sorte, narra as agruras cotidianas de um jovem casal de classe média baixa em

19 As informações técnicas referentes aos filmes foram obtidas na base de dados Filmografia Brasileira, da Cinemateca Brasileira. Ver: <http://cinemateca.gov.br/cgibin/wxis.exe/iah/?IsisScript=iah/iah.xis\&base=FILMOGRAFIA\&lang=p\&nextAction=lnk\&exprSe arch=ID=019186\&format=detailed.pft\#1>. Acesso em: 13 abr. 2015. 
dificuldades financeiras: Jorge (Carlos Carvalho) e Maria (Araci Esteves). Ele trabalha como motorista de ônibus, ela como comerciária. Apesar do intenso labor a vida segue tranquila até que Jorge perde o emprego, Maria engravida e a prestação da casa própria não para de chegar.

Em Vida nova por acaso temos as peripécias de dois malandros, Crioulo (Odilon Lopez) e Magrão (Francisco Silva), que saem da cadeia e sonham com uma vida nova. Reincidem no que sabem fazer melhor, roubar a carteira dos transeuntes. Ocorre que as vítimas também estão sem dinheiro. Então uma loura rica (Ângela Groisser) entra na vida de Crioulo e o leva para um cotidiano de festa e ostentação. A farsa termina e os ricaços descobrem os dois malandros que, depois de quase serem linchados, são reconduzidos à prisão.

Um é pouco, dois é bom foi realizado em um contexto favorável à produção cinematográfica riograndense. A partir do final da década de 1960 o cinema gaúcho ganhou fôlego com os incentivos dados pelo Banco Regional de Desenvolvimento do Extremo Sul. Embora não tenha recebido dinheiro do referido banco, algumas instituições e pessoas públicas apoiaram a realização do filme. Declarou Lopez na época:

O financiamento já está assegurado, contando com a colaboração efetiva do Governo do Estado do RGS, Prefeitura Municipal e Banco do Estado do RGS que financiaram a produção. Como fazer cinema, todo mundo está cansado e saber que é uma luta, estamos contando com a colaboração de toda a cidade, desde indústrias, casas comerciais etc. ${ }^{20}$

Os letreiros agradecem ao governador Walter Perachi de Barcellos, ao prefeito de Porto Alegre Telmo Thompson Flores, ao jun. 1970.

20 Ver "Cinema gaúcho parte agora para temas urbanos." Folha da tarde. São Paulo, 09 
Dr. Willy Victor Sanvitto do Banco do Estado do Rio Grande do Sul, aos cônsules da Alemanha e Grã-Bretanha, entre outros.

Diferente dos primeiros tempos como repórter cinematográfico, aos 29 anos Odilon dominava o ofício de cineasta. Parte do aprendizado viera da experiência adquirida nos anos 1950, quando trabalhou nos estúdios no Rio de Janeiro. Naquele contexto os filmes eram produzidos com poucos recursos, o que exigia improvisos, agilidade e inventividade dos artistas e técnicos para superarem a precariedade. Ele aplicou os conhecimentos aprendidos: "Para o levantamento da produção, foram de extrema valia os anos vividos durante a crise dos anos 50, que me ensinaram a insistir apesar dos desencontros ocasionais." (LOPEZ, 1982, p. 18).

Por conseguinte, a prática adquirida na realização de reportagens e documentários para a televisão deu-lhe agilidade de produção e o controle da direção em locações externas, predominantes no filme. No final da década de 1960 Odilon era reconhecidamente um homem de cinema e televisão.

Um é pouco, dois é bom foi um dos primeiros filmes a romper com a temática rural que predominava nos filmes gaúchos até então. Estes desagradavam parte da crítica que os chamavam, um tanto depreciativamente, de "cinema de bombachas". ${ }^{21}$

Nas décadas de 1970 e 80, a produção de curtas e longas metragens esteve restrita, inicialmente, ao formato super8. A evolução do super-8 para 16 e $35 \mathrm{~mm}$ foi tão natural quanto do curta para o longa metragem, marcada pela atuação de um grupo de jovens produtores e diretores de Porto Alegre, entre os quais estavam Giba Assis Brasil, Carlos Gerbase, Werner Schunemann, Antonio Carlos

21 Sobre a temática regionalista no campo cinematográfico gaúcho ver: ROSSINI, M. S. Cinema gaúcho: construção de história e identidade. Nuevo Mundo, Mundos Nuevos. 2007. Disponível em: http://nuevomundo.revues.org/3164. Acessado: 19 abr. 2015; FELIZARDO, C. K. Entre o prazer e o pudor: representações do sexo e da sexualidade no cinema produzido no Rio Grande do Sul. 2011, 202 f. Dissertação (Mestrado em Comunicação) - Faculdade de Comunicação Social, PUCRS, Porto Alegre, 2011; GERBASE, C. Nelson Nadotti e a Invenção do Gaúcho Urbano. e compós - Revista da Associação Nacional dos Programas de Pós-Graduação em Comunicação, vol. 2, abr. 2005. <http://www.compos.org.br/seer/index.php/ecompos/article/viewFile/31/32>. Data de acesso: 19 abr. 2015. 
Textor, Nélson Nadotti, Odilon Lopez e Sérgio Silva, todos abertamente contrários as tendências de retratar as temáticas históricas ou os espaços rurais, que eles chamavam ironicamente de "cinema de bombachas" (BUNDT, 2005).

A imprensa noticiou a novidade: "O sul parte para o cinema urbano. Já começaram, em Porto Alegre, as filmagens de "Um é pouco, dois é bom". O filme é a cores, com duas histórias e representa a primeira tentativa de se fazer um cinema urbano no Rio Grande do Sul." 22 A Folha da Tarde publicou em junho de 1970:

Depois de explorar um pouco a bombacha, o cinema gaucho parte para os temas urbanos. Dia 30 deste mês, estarão sendo iniciadas as filmagens de "Um é pouco, dois é bom", película em cores com duas historias distintas (...) que vai mostrar outros aspectos do RGS: a grande cidade, nossas mulheres usando roupas segundo as últimas criações da moda (muita maxi e midi), as particularidades do inverno gaúcho e o caldeamento de raças existente, com tipos humanos diversos do restante do país." 23

De fato a cidade é sobrevalorizada no filme com várias cenas filmadas em locações externas entre os seus moradores. Ela é evidenciada em planos gerais e panorâmicas sobre prédios, ruas, estádios de futebol, dentro de automóveis, bares, restaurantes etc. É a personagem principal e funciona como uma moldura que constrói a continuidade entre os dois episódios. Sua presença faz com que as duas histórias sejam crônicas da vida de qualquer grande centro urbano do Brasil.

1970.

22 Ver "O sul parte para o cinema urbano." O Estado de São Paulo. São Paulo, 05 jul. jun. 1970.

23Ver "Cinema gaúcho parte agora para temas urbanos." Folha da tarde. São Paulo, 09 
As filmagens foram concluídas em setembro de 1970. Em novembro do mesmo ano estreou comercialmente em uma das principais salas de Porto Alegre, o Cinema Victória e circuito. Segundo Odilon a recepção do público foi satisfatória: "A acolhida foi muito boa. A crítica em geral não somente foi favorável ao filme em si, como ao novo rumo proposto ao cinema gaúcho." (LOPEZ, 1982, p. 18).

Não é o que se deduz do artigo do crítico de cinema P.F Gastal que após elogiar o filme reclama do público e dos críticos que reivindicavam um cinema urbano.

Agora, com Um é pouco, dois é bom... Odilon Lopez põe em prática o tão reclamado cinema urbano. Em sua fita Porto Alegre, sob certos aspectos, é a grande vedeta, com sequencias que mostram a Rua da Praia em pleno pique; o estádio Beira-rio, o Parque da Redenção, interiores e exteriores de lojas locais. Os personagens nada tem de grossos: são gente da cidade, moderna, pra-frentex, bem vestida. Tudo mostrado em duas histórias que se caracterizam pela inventividade e imaginação sobretudo a segunda - narradas na base de uma das mais belas fotografias a cores do cinema. Infelizmente, porém, o público não tem correspondido a esse esforço. Onde estão aqueles que pediam o cinema urbano?" (BECKER, 1996, p. 204).

Já a distribuição e a comercialização fora do território gaúcho foi desastrosa. Para piorar, a censura restringiu o filme para menores de idade, o que o privou de uma fatia do público habitual das salas de exibição. Odilon se queixou da classificação feita por alguns críticos, o que segundo ele estigmatizou o filme: "Mesmo assim, o filme pagou-se. Lamento apenas que na época alguns o tenham classificado como 'filme de arte.' " (LOPEZ, 1982, p. 18). Quanto à recepção na comunidade negra, não foi percebida: "Com exceção do Zózimo Bulbul, que me deu força, não houve outras manifestações que eu retenha na memória." (LOPEZ, 1982, p. 18). 
O retorno da bilheteria foi questionado pelo historiador do cinema gaúcho Tuio Becker que escreveu: "Orçado em Cr\$200 milhões da época, Um é pouco, dois é bom não se pagou até hoje (BECKER, 1986, p. 34). ${ }^{24}$

O filme foi exibido em festivais e mostras. Participou da II Mostra do Cinema Brasileiro de Guarujá e da Mostra Internacional do Festival de Gramado.

\section{O passado no presente}

A trajetória artística de Odilon é semelhante à dos atores e cineastas negros da sua geração. Nela se combinam migração das antigas áreas de plantation para zonas urbanas em busca de novas oportunidades de trabalho, certa desagregação familiar, vida escolar descontínua, autodidatismo, subemprego, trabalho precoce em novas frentes de trabalho e em campos pouco profissionalizados - como o audiovisual, por exemplo. Viveu a infância e a juventude em uma sociedade em acelerada transformação, onde traços da sociedade rural de passado escravista sobreviviam ao lado da modernidade urbana e industrial em formação. Esses traços aparecerão no seu filme de estréia.

Quando investigamos sua vida, nos raros documentos publicados, encontramos pouquíssimas referências sobre a família paterna e materna. Sabemos que ficou órfão muito cedo, passou parte da infância em Belo Horizonte com o avô e em um abrigo para menores no Rio de Janeiro. Não encontramos tampouco referências sobre sua educação escolar.

Iniciou cedo no trabalho e teve diversas ocupações. Estudou atuação e ingressou no cinema ainda adolescente. Esta experiência carioca certamente facultou-lhe a ida à Porto Alegre para trabalhar na para o cinema urbano." O Estado de São Paulo. São Paulo, 05 jul. 1970. 
recém implantada televisão gaúcha. O novo ambiente de trabalho era favorável para quem tivesse experiência na área de comunicação. Nele Odilon desempenhou várias funções: ator, cinegrafista, repórter, documentarista e diretor de ficções. Autodidata, aprendeu a falar e a ler inglês e, patrocinado pela televisão, fez cursos no exterior que lhe qualificaram profissionalmente.

Realizou seu longa-metragem também muito jovem, com apenas 29 anos. A precocidade chama atenção quando levamos em consideração o acúmulo de funções desempenhadas: produtor, roteirista, diretor e ator (no segundo episódio).

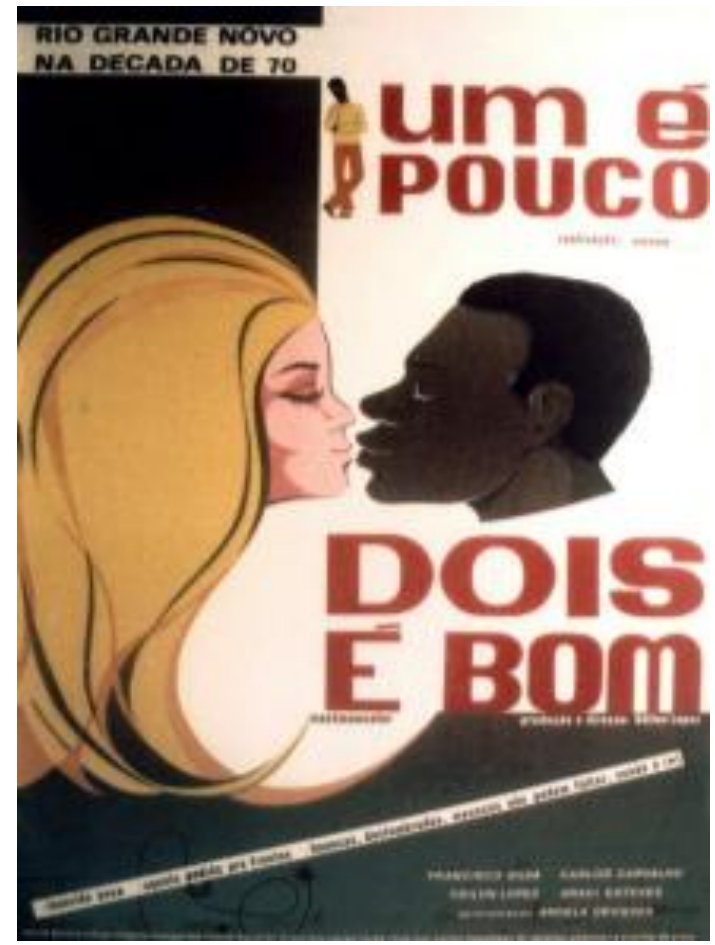

Imagem 4 Foto do cartaz original de Um é pouco, dois é bom

(Odilon Lopez, 1970) 
Odilon tampouco identifica qualquer preconceito vivido na realização do filme: "Não acredito que o fator cor tenha influído negativamente, antes pelo contrário. Embora o Rio Grande do Sul seja um estado de formação étnica preponderantemente européia, não tive também dificuldades com o elenco." (LOPEZ, 1984, p. 18).

De um ponto de vista sociológico a afirmação resulta da negação de negros e mulatos em ascensão social em identificar o preconceito racial nas suas trajetórias de vida, tal como apontam IANNI e FERNANDES (1960) no estudo que fizeram sobre as relações raciais no sul do país. A posição social de Odilon conta nesta recusa: homem de imprensa com uma história política na cidade, oriundo de uma grande metrópole, conhecido de intelectuais e artistas, qualificado como cineasta e que realizava um filme identificado com os anseios de uma elite intelectual interessada em romper com traços identificados por ela como arcaicos. Seu filme não abordava o racismo diretamente e o fato de ser negro e gozar da posição de cineasta, se desagradava alguns, para outros coroava a modernidade desejada. Embora o casal inter-racial do segundo episódio chame nossa atenção, não há nele a intenção deliberada em discutir o racismo.

O crítico Luiz Carlos Merten (2002, p. 56-57) pensa diferente e propõe uma interessante hipótese para o filme. Para ele o episodio Vida nova por acaso faz uma critica irônica do racismo. Ao mesmo tempo inscreve o personagem Crioulo na tradição de outros personagens negros veículos de critica social.

De um golpe, o ator e diretor inova duplamente. Trata, com humor e razoáveis doses de humanidade e crítica social, a questão do racismo e também se inscreve num movimento comum a todo o cinema brasileiro daqueles anos de chumbo: o malandro que Grande Otelo interpretava nas chanchadas e em filmes como Amei um bicheiro, de Jorge Ileli, o próprio compositor de Rio zona norte, de Nelson Pereira dos Santos, ambos dos anos 1950, fazia sua passagem para um comportamento mais próximo do banditismo. A barra iria pesar muito mais em outros filmes que marcaram o cinema brasileiro dos anos 1970, como o importantíssimo A Rainha Diaba, de 


\begin{abstract}
Antonio Carlos da Fontoura. Tudo isso - a questão social, o racismo, a urbanidade - já está em Um é pouco, dois é bom (...) e confere importância a um filme que não chegou a fazer muito sucesso de público nem de crítica.
\end{abstract}

Novos estudos diretamente sobre o filme e a relação com outros personagens negros podem ampliar este argumento.

Um é pouco, dois é bom não agradou aos críticos. Nem mesmo aos ansiosos por um cinema urbano e que haviam festejado sua produção antes da estréia. De fato quando assistimos aos dois episódios vemos que a cidade mostrada, e até certo ponto celebrada, não é vista como símbolo da modernidade. Ao contrário ela é o espaço da alienação. Os personagens vivem dificuldades originadas pelo meio urbano, como o desemprego, a pobreza, a falta de moradia etc. Eles tampouco são refinados, cosmopolitas ou identificados com os requintes da vida moderna. Ao contrário, seu modo de vida e linguajar lembram os migrantes das zonas rurais, trabalhadores pobres, pouco escolarizados, habitantes das periferias e marginais sociais. O que evidentemente frustrou os anseios de parte da intelectualidade ansiosa pelos sinais ostentatórios da urbanidade.

Não é exagero afirmar que Odilon registra a cidade ao lado dos seus personagens marginais. Não há nele a distância crítica dos filmes do Cinema Novo que, através dos personagens de classe média, fazem a mediação entre o cineasta e o povo. No dois episódios do filme estamos imersos em um mundo rural, porém agora dentro da cidade. O que vemos é uma bem humorada crônica social sobre a vida difícil de migrantes que têm que se adaptar à cidade grande.

É esse exatamente este o tema das chanchadas nas quais Odilon iniciou a carreira. Nesse sentido Um é pouco, dois é bom biografa a trajetória do seu realizador de duas perspectivas: do ponto de vista da sua trajetória migrante e da sua experiência profissional. A identificação com Carlitos e o filme Luzes da Cidade refazem a liga.

Finalmente vale destacar o protagonismo de Odilon Lopez. Ele foi o primeiro diretor negro a ter o controle quase total sobre a sua obra. Ocupou as posições que definem o sentido da história. Escolheu a dedo os colaboradores além de conceber, produzir, dirigir e atuar. Antes dele apenas Cajado Filho e Haroldo Costa haviam dirigido 
filmes nos anos 1950. No entanto, nenhum deles assumiu as principais funções para a construção do sentido. Trabalharam quase sempre sob encomenda de produtores.

Poucos anos depois outro diretor negro, Zózimo Bulbul, iniciou seu primeiro filme, o curta-metragem Alma no olho (Zózimo Bulbul, 1973), mas essa já é outra história.

\section{Referências bibliográficas}

BALBI, M. Fernando Peixoto: em cena aberta. São Paulo, Imprensa Oficial do Estado de São Paulo, 2009.

BECKER, T. O cinema Gaúcho - uma breve história. Porto Alegre, Ed. Movimento, 1986.

BECKER, T. (Org.). Cadernos de cinema de P.F. Gastal. Porto Alegre, Ed. Unidade, 1996.

BORDWELL, D. Figuras traçadas na luz - a encenação do cinema. Campinas, Papirus, 2009.

BUNDT, R. L. C. (2005). A regionalidade do cinema gaúcho. Disponível em: <http://encipecom.metodista.br/mediawiki/images/7/73/GT3-_10_A_regionalidade-Roger.pdf>. Data de acesso: 22 abr. 2015.

CARDOSO, F.H; IANNI, O. Cor e mobilidade social em Florianópolis. São Paulo, Compnahia Editora Nacional, 1960.

CASTRO, N. A. P. Televisão e presidência da república: a soberania em disputa de 1950 a 1964. 2011. 322 p. (Tese de Doutorado, Ciência Política) - Universidade Federal do Rio Grande do Sul, Porto Alegre, 2011.

CAUDURO, M. Palavras do tempo. Porto Alegre, AGE Editora, 2000. 
CARVALHO, N. S. Produção, Mercado Cinematográfico e Ideologia Nacionalista - O Cinema Brasileiro Sob a Égide do Nacional Popular nos Anos 50. Ponta de Lança (UFS), Sergipe, V. 6, n 12, 2012. Disponível em: <http://seer.ufs.br/index.php/pontadelanca/article/view/3326>. Acesso em: 05 abr. 2015.

. Cinema e representação racial - o cinema negro de Zózimo Bulbul. 2006. 302 p. (Tese de Doutorado em Sociologia) Universidade de São Paulo, São Paulo, 2006;

- Racismo e anti-racismo no Cinema Novo. In: Esther Hamburguer, Gustavo Souza, Leandro Mendonça, Túnico Amancio. (Org.). Estudos de Cinema SOCINE. São Paulo: Anablume, 2008, v. , p. 53-60.

LOPEZ, O. A. Odilon Lopez: depoimento. (agosto/outubro de 1982). Rio de Janeiro, Revista Filme Cultura. Entrevista concedida a João Carlos Rodrigues.

. "Movidos pelo carisma de um revolucionário." In: CHEUICHE, A. (Org.). Nós e a legalidade, depoimentos. Porto Alegre, Editora AGE, 1991.

MARKUN, P.; HAMILTON, D. 1961: Que as armas não falem. São Paulo, SENAC, 2001.

MERTEN, L. C. Cinema gaúcho. São Leopoldo, Editora Unisinos, 2002.

NEVES, David. O cinema de assunto e autor negros no Brasil. In: Cadernos Brasileiros: 80 anos de abolição. Rio de Janeiro, Editora Cadernos Brasileiros, ano 10, n. 47, p. 75-81, 1968.

PEREIRA. M. O Columbianum e o cinema brasileiro. Alceu, Rio de Janeiro, v.8, n.15, p. 127 a 142, jul./dez. 2007.

RAMOS, F. (Org.). História do cinema brasileiro. São Paulo, Art. Editora, 1990.

RAMOS, A. G. Introdução crítica à sociologia brasileira. Rio de Janeiro: UFRJ, 1995, p. 200. 
REIS, L. P. S. O backstage da televisão no Rio Grande do Sul. 2012. 296 p. (Dissertação de mestrado em Comunicação Social) - Pontifícia Universidade Católica do Rio Grande do Sul, Porto Alegre, 2013.

SILVA NETO, A. L. Dicionário de fotógrafos do cinema brasileiro. São Paulo, Imprensa Oficial do Estado de São Paulo, 2010.

VIANY, A. Vitória do Cinema Novo: Gênova. In: Revista Civilização Brasileira, ano I, n. 2, p. 227-48, 1965.

XAVIER, I. Do golpe militar à abertura: a resposta do cinema de autor. In: XAVIER, I; BERNARDET, J - C; PEREIRA, M. O desafio do cinema. Rio de Janeiro: Jorge Zahar, 1985. RAMOS, F. (Org.). História do cinema brasileiro. São Paulo: Art. Editora, 1990.

RECEBIDO EM: 02/01/2016 APROVADO EM: 19/04/2016 